All the changes in the original design of the institution clearly show the marked improvement in the style of buildings of the present day from the dreary prisonlike structure of over seventy years ago. It is interesting to note on going over the records the anxiety of the Governors to provide for and ameliorate, if possible, the condition of the lunatic poor of the district; this is characteristic of the people of Waterford, who are remarkable for their charitable disposition. A stranger coming to live among them cannot help being struck by the number of charitable institutions in the city and by the generous help always afforded to the deserving poor.

Dr. Mary S. P. Strangman, introduced by the Chairman, read a paper entitled, "The Atropin Treatment of Morphinomania and Inebriety," which was discussed by the Hon. Secretary and Drs. Leeper, Eustace, James Fitzgerald, and West (see page 727).

Hearty votes of thanks were unanimously passed to Dr. Oakshott for his conduct in the chair and his kind hospitality; to J. N. White, Esq., M.R.I.A., for kindly lending his steam-launch for the use of the members; and to Dr. Strangman for her paper; and Dr. Oakshott having replied for himself and Dr. Strangman, the meeting terminated.

\title{
COMPLIMENTARY.
}

\section{THE PRESENTATION OF THE FREEDOM OF KIRKWALL TO} DR. CLOUSTON.

THE freedom of the Royal Burgh of Kirkwall in far Orkney has been conferred on Dr. Clouston, who was surrounded by his family and friends on that auspicious occasion. Provost Slater said that the list of distinguished men on the Burgess' Roll was honourable because each of them had been a man of outstanding distinction in the country. Dr. Clouston had conferred distinction on the county, of which Kirkwall was the chief town, and came of an old Orkney family who have held lands there for very many years. Provost Slater proceeded to sketch Dr. Clouston's career, with which we are all familiar; and referred to his kindness and hospitality, specially to Orcadians; his help and his influence had been a boon and a blessing to many. Provost Slater handed the burgess ticket to Dr. Clouston. It was engrossed as follows:

KIRKwall, the twenty-eighth day of August, one thousand nine hundred and eight.-Which day the Magistrates of the Royal Burgh of Kirkwall admitted Thomas Smith Clouston, Esq., M.D., LL.D.Edinburgh, a Burgess and Guild Brother of the said Burgh, with all the privileges and immunities thereto belonging, on the occasion of his first visit since his recent retirement from the arduous duties of Medical Superintendent of the Royal Edinburgh Asylum after a service of thirty-five years, in recognition of his very distinguished professional career, of his world-wide reputation as an authority on mental diseases, of the additions he has made to the literature of his profession, and of the deep interest he has always taken in his native county of Orkney. This Burgess and Guild Brother Ticket was directed to be prepared and delivered to him, the said Thomas Smith Clouston, by acceptance hereof, becoming solemnly bound to discharge every civil duty incumbent by law on a true and faithful Guild Brother of the said Burgh. A memorandum of which admission, written upon stamped paper, is enrolled among the records of the said Burgh.-In witness whereof, these presents are subscribed by the said Magistrates and by the Town Clerk, and the seal of the Burgh is impressed hereon.

$$
\begin{aligned}
& \text { Jas. Slater, Provost. } \\
& \text { WM. B. Baikie, Senior Bailie. } \\
& \text { WM. F. White, Junior Bailie. } \\
& \text { WM. J. Hedde, Town Clerk. }
\end{aligned}
$$

Provost Slater in handing the burgess ticket to Dr. Clouston remarked, amid cheers, that he had great pleasure in doing so on behalf of the citizens of the Royal Burgh. 
Dr. Clouston, in acknowledging the honour conferred upon him, said that he was never so pleased with anything in his life. Being an Orcadian, bearing a name which is absolutely Orcadian, and a name found nowhere else but when borne by Orcadians and descendants of Orcadians, it was specially gratifying that he should be asked to receive the greatest honour which the Town Council of Kirkwall could confer on any citizen. There had been comparatively few men within the last hundred years who had received this great distinction, and so it was doubly welcome and doubly appreciated. Dr. Clouston referred to the work of his life, and indicated that statesmen should turn their attention to the sons of Orkney and Shetland to reinvigorate the race. Dr. Clouston then signed the Burgess Roll, and was afterwards entertained to a banquet in the Kirkwall Hotel, where the proceedings were enthusiastic and cordial. We feel sure that $\mathrm{Dr}$. Clouston's many friends will compliment him upon this new honour which has been so kindly conferred upon him. They best know how well deserved it was. We need only add our congratulations to Dr. Clouston, and express our best wishes.

\section{DR. MAGNAN}

Dr. Magnan's jubilee has been honoured in Paris by a concourse of distinguished friends. For forty years he has been physician to the admission block of St. Anne's Asylum, and his former fellow-student, Dr. Bouchard, presided at the festival. Dr. Magnan was presented with a beautiful plaque, the work of Professor Richer of the Institute; and the subscribers are to receive replicas in the form of medals. Well-known colleagues were present, Dr. Ritti, representing the MedicoPsychological Society ; Drs. Briand and Sérieux, speaking in the name of former pupils ; Dr. Ladame for Switzerland ; and Dr. Bagenof for Russia. Dr. Mierzejewsky had been chosen by his friends to represent them, had journeyed to Paris for the purpose, but the calamity of his sudden and fatal disease occurred on the very day of the ceremony.

Dr. Sérieux said, My dear master, observer, investigator, incomparable clinician, you have upheld the glorious traditions of French psychiatry, and it is to you we owe the present position of our branch of medicine. We cannot forget that you are also a teacher and the benefactor of your patients. I hardly see anyone here who has not been your pupil, directly or indirectly. Teacher you certainly are, not only by way of formulz, but also by your good deeds and the thorough performance of your daily duty. Devoted to duty not only in the advancement of science but also in the care of your patients-finding words of comfort for them and combatting the coalition of routine with ignorance-we find to have been an education of the best. We have not only had our preference for mental pathology developed, but have found it revivified by your published works. Your influence has permeated France, and spread throughout the world where your pupils are scattered. Your life has been a valuable lesson on which to meditateune excitation à bien penser et à bien faire. You have lived among your patients, disdaining publicity, taking no account of popularity, which some so often use to conquer. You require much of your colleagues, but are still more exacting of yourself. I have seen you late at night calming one patient and comforting another. I have heard them pour forth their troubles to you while I was lost in admiration. Your ardour is unabated after forty years of work here. Here is your life and the unity of it is splendid. Without your personal influence what prejudices would yet live, how many unfortunate patients would yet wear straitwaistcoasts in absolute isolation? We bow to-day before the master and benefactor.

\section{CONOLLY NORMAN MEMORIAL FUND.}

Thr Honorary Treasurers of this Fund will be greatly obliged if all intending subscribers will forward their contributions at an early date. 